\title{
Serum Antithrombin III Level In Children with Nephrotic Syndrome
}

\author{
Ahmed Albanna ${ }^{1}$, Hadeer Abd Elghafar ${ }^{2}$, Sherin Khamis ${ }^{2}$ \\ 1: Pediatric department, Suez Insurance Hospital \\ 2: Pediatric department, Faculty of Medicine, Fayoum University
}

\begin{abstract}
Objectives: The aim of the study was to predict the possible risk of thromboembolic complication development in children with nephritic syndrome due to antithrombin III deficiency and to compare between serum levels of antithrombin III in patients with nephritic syndrome during both relapsing and after 6 weeks of the start of steroid treatment.
\end{abstract}

Methods: This study was conducted in outpatient Nephrology Clinic of Children's Hospital, Fayoum University. It included 27 children with nephrotic syndrome to be followed during both relapse and after 6 weeks after start of steroid therapy, and 27 healthy children as control group.

Results: There were significant decreases in antithrombin III, albumin and total proteins levels in the study group during relapse and after steroid therapy their levels were improved while there were significant increases in platelet count, cholesterol, triglycerides levels during relapse which also improved after steroid therapy. There was no thromboembolic complications detected among the study group.

Conclusions: Antithrombin III level is significantly decrease in children with nephritic syndrome and despite of the hypercoagulable state no thromboembolic complications can be detected in children with nephrotic syndrome.

Keywords: Nephrotic syndrome, Antithrombin III, Steroid therapy, Hypercoagulable state, Thromboembolic complications. 


\section{Introduction}

Childhood nephrotic syndrome is one of the most common of pediatric kidney diseases, which has an incidence of 2-7 per 100000 children [1]. It is characterized by a triad of proteinuria, edema, and hypoalbuminemia [2]. In a healthy individual, less than $0.1 \%$ of plasma albumin may traverse the glomerular filtration barrier [3]. The glomerular capillaries are lined by a fenestrated endothelium that sits on the glomerular basement membrane, which in turn is covered by glomerular epithelium, or podocytes, which envelops the capillaries with cellular extensions called foot processes. In between the foot processes are the filtration slits [4]. The glomerular structural changes that may cause proteinuria are damage to the endothelial surface, the glomerular basement membrane, or the podocytes. One or more of these mechanisms may be seen in any type of nephrotic syndrome [5]. Nephroticrange proteinuria is the loss of 3 grams or more per day of protein into the urine or on a single spot urine collection, the presence of 2 grams of protein per gram of urine creatinine [4]. Nephrotic syndrome can be associated with a series of complications that can affect an individual's health and quality of life. Thromboembolic disorders: particularly those caused by a decrease in blood antithrombin III levels due to leakage [6]. Antithrombin III is a naturally occurring inhibitor of blood coagulation. It is a $\alpha 2$ - globulin member of the serin group, found in the plasma and various extravascular sites. It inactivates thrombin as well as certain coagulation factors (VIIa, IXa, Xa \& XIa) [7]. Antithrombin III is synthesized primarily in the liver. It is secreted into the plasma. The plasma half-life is approximately 3 days. Thus, even short periods of low AT III plasma level may lead to potential thrombosis [8].

\section{Patients and Methods:}

This cross-sectional composed of 2 groups(study group and control group). The study included 27 children diagnosed as relapsing nephrotic syndrome (15 males and 12 females with a male to female ratio 1.25:1). Patients were recruited from regular attendants of the Pediatric Nephrolog Clinic, Fayoum University Hospital during the period from May to December 2016. Twenty seven age- and sex- matched healthy subjects were enrolled as a control group. An informed consent was obtained from the guardian of 
each patient and control before participation. This study was reviewed by the Faculty of Medicine Research Ethical Committee. All children in the study were subjected to complete thorough history taking and physical examination. Laboratory investigations were done in the form of complete blood picture, serum levels of albumin, total protein, creatinine, urea, cholesterol, triglycerides and serum atithrombin III level with double-sandwich ELISA technique, using commercially available kit (MyBioSource, USA Cat\#MBS268161).Also urine analysis, albumin/creatinine ratio, prothrombin tim and INR were done. Pelvi-abdominal ultrasound was done for children to exclude renal vein thrombosis and ascites. Investigations were repeated to children with nephrotic syndrome after 6 weeks of the start of steroid therapy.

Statistical Analysis Data were collected and coded to facilitate data manipulation and double entered into Microsoft Access and data analysis was performed using SPSS software version 18 in windows 7. Simple descriptive analysis in the form of numbers and percentages for qualitative data, and arithmetic means as central tendency measurement, standard deviations as measure of dispersion for quantitative parametric data, and inferential statistic test: For quantitative parametric data: Independed student tTest used to compare measures of two independent groups of quantitative data. One way ANOVA test in comparing more than two independent groups of quantitative data. Kruskal wallis test used in comparing more than two independent nonparametric groups. Mann-whitney test in comparing two independent nonparametric groups. For qualitative data Chi square test to compare two of more than two qualitative groups. Bivariate pearson correlation test to test association between variables. The level $P$ $\leq 0.05$ was considered the cut-off value for significance.

\section{Results}

This cross-sectional study included 27 patients as the study group, recruited from attendants of the pediatric nephrology clinic and 27 age- and sex-matched healthy subjects as a control group. The mean age of the study group was 5.78 years with a range between 3 and 10 years. Males constituted 55.6\% of the group while males constituted $44.4 \%$. 
Table 1: Comparison between results of samples collected from control group and study group at the start of the study that showed statistically significant decrease in serum albumin, total protein and antithrombin III values of the study group in comparison with the control group while there was statistical significant increase in serum cholesterol an tri glycerides, platelet count and albumin/ creatinine ratio in the study roup in relation with the control group. Alb: albumin T.pt: total protein AT III: antithrombin III Cho: cholesterol Tri-Gly: tri glycerides Creat: creatinine A/C: albumin/ creatinine Pt: prothrombin time.

\begin{tabular}{|l|l|l|l|l|l|l|l|l|l|l|l|}
\hline & $\begin{array}{l}\text { Alb } \\
\text { g/dl }\end{array}$ & $\begin{array}{l}\text { T.pt } \\
\text { g/dl }\end{array}$ & $\begin{array}{l}\text { AT III } \\
\text { ng/ml }\end{array}$ & $\begin{array}{l}\text { Chol } \\
\mathrm{mg} / \mathrm{dl}\end{array}$ & $\begin{array}{l}\text { Tri-Gly } \\
\mathrm{mg} / \mathrm{dl}\end{array}$ & $\begin{array}{l}\text { Platelet } \\
1000 / \mathrm{mc} \\
1\end{array}$ & $\begin{array}{l}\text { Urea } \\
\mathrm{mg} / \mathrm{dl}\end{array}$ & $\begin{array}{l}\text { Creat } \\
\mathrm{mg} / \mathrm{dl}\end{array}$ & $\begin{array}{l}\text { A/C } \\
\text { ratio }\end{array}$ & $\begin{array}{l}\text { Pt } \\
(\mathrm{sec})\end{array}$ & I N R \\
\hline $\begin{array}{l}\text { Study } \\
\text { group } \\
\text { (mean) }\end{array}$ & $\begin{array}{l}1.87 \pm \\
0.48\end{array}$ & $\begin{array}{l}4.32 \pm \\
0.70\end{array}$ & $\begin{array}{l}81.74 \pm \\
20.1\end{array}$ & $\begin{array}{l}359.3 \pm \\
104.83\end{array}$ & $\begin{array}{l}295.8 \pm \\
66.25\end{array}$ & $\begin{array}{l}489.33 \pm \\
65.90\end{array}$ & $\begin{array}{l}14.70 \pm \\
5.76\end{array}$ & $\begin{array}{l}0.26 \pm \\
0.11\end{array}$ & $\begin{array}{l}550.6 \pm \\
99.99\end{array}$ & $\begin{array}{l}12.1 \pm \\
0.81\end{array}$ & $\begin{array}{l}1.05 \pm \\
0.05\end{array}$ \\
\hline $\begin{array}{l}\text { Control } \\
\text { group } \\
\text { (mean) }\end{array}$ & $\begin{array}{l}4.08 \pm \\
0.45\end{array}$ & $\begin{array}{l}7.01 \pm \\
0.66\end{array}$ & $\begin{array}{l}170.77 \pm \\
11.03\end{array}$ & $\begin{array}{l}168.4 \pm \\
17.37\end{array}$ & $\begin{array}{l}135.96 \pm \\
30.48\end{array}$ & $\begin{array}{l}268.78 \pm \\
83.32\end{array}$ & $\begin{array}{l}13.89 \pm \\
6.64\end{array}$ & $\begin{array}{l}0.23 \\
0.12\end{array}$ & $\begin{array}{l}15.26 \pm \\
6.58\end{array}$ & $\begin{array}{l}11.85 \pm \\
2.31\end{array}$ & $\begin{array}{l}1.06 \pm \\
0.06\end{array}$ \\
\hline P-value & $\mathbf{0 . 0 0 1}$ & $\mathbf{0 . 0 0 1}$ & $\mathbf{0 . 0 0 1}$ & $\mathbf{0 . 0 0 1}$ & $\mathbf{0 . 0 0 1}$ & $\mathbf{0 . 0 0 1}$ & 0.632 & 0.353 & 27.760 & 0.595 & 0.322 \\
\hline
\end{tabular}

Table 2: Comparison between results of samples collected from control group and study group after 6 weeks of steroid therapy that showed improvement of albumin total protein and antithrombin III levels of the study group but still lower than that of the control group. Also there was decrease in cholesterol and tri glycerides levels in the study group but still higher than that of the control group. Alb: albumin T.pt: total protein AT III: antithrombin III Cho: cholesterol Tri-Gly: tri glycerides Creat: creatinine A/C: albumin/ creatinine Pt: prothrombin time.

\begin{tabular}{|c|c|c|c|c|c|c|c|c|c|c|c|}
\hline & $\begin{array}{l}\text { Alb } \\
\mathrm{g} / \mathrm{dl}\end{array}$ & $\begin{array}{l}\text { T.pt } \\
\text { g/dl }\end{array}$ & $\begin{array}{l}\text { AT III } \\
\mathrm{ngm} / \mathrm{l}\end{array}$ & $\begin{array}{l}\text { Chol } \\
\mathrm{mg} / \mathrm{dl}\end{array}$ & $\begin{array}{l}\text { Tri-Gly } \\
\mathrm{mg} / \mathrm{dl}\end{array}$ & $\begin{array}{l}\text { Platelet } \\
1000 / \mathrm{mcl}\end{array}$ & $\begin{array}{l}\text { Urea } \\
\mathrm{mg} / \mathrm{dl}\end{array}$ & $\begin{array}{l}\text { Creat } \\
\mathrm{mg} / \mathrm{dl}\end{array}$ & $\mathrm{A} / \mathrm{C}$ ratio & $\begin{array}{l}\mathrm{Pt} \\
(\mathrm{sec})\end{array}$ & IN R \\
\hline $\begin{array}{l}\text { Study } \\
\text { group } \\
\text { (me'an) } \\
\text { After } 6 \\
\text { weeks } \\
\text { of } \\
\text { steroid } \\
\text { therapy }\end{array}$ & $\begin{array}{l}3.58 \pm \\
0.48\end{array}$ & $\begin{array}{l}6.49 \pm \\
0.83\end{array}$ & $\begin{array}{l}168.1 \pm \\
13.1\end{array}$ & $\begin{array}{l}207.44 \pm \\
24.00\end{array}$ & $\begin{array}{l}167.78 \quad \pm \\
20.91\end{array}$ & $\begin{array}{l}311.78 \quad \pm \\
116.77\end{array}$ & $\begin{array}{l}15.33= \\
14.47\end{array}$ & $\begin{array}{l}0.23 \pm \\
0.07\end{array}$ & $\begin{array}{l}25.63 \quad \pm \\
3.70\end{array}$ & $\begin{array}{l}11.28 \pm \\
2.12\end{array}$ & $\begin{array}{l}1.05 \pm \\
0.06\end{array}$ \\
\hline $\begin{array}{l}\text { Control } \\
\text { group } \\
\text { (mean) }\end{array}$ & $\begin{array}{l}4.08 \pm \\
0.45\end{array}$ & $\begin{array}{l}7.01 \pm \\
0.66\end{array}$ & $\begin{array}{l}170.77 \pm \\
11.3\end{array}$ & $\begin{array}{l}168.4 \pm \\
17.37\end{array}$ & $\begin{array}{l}135.96 \pm \\
30.48\end{array}$ & $\begin{array}{ll}268.78 \quad \pm \\
83.32\end{array}$ & $\begin{array}{l}13.89 \pm \\
6.64\end{array}$ & $\begin{array}{ll}0.23 & \pm \\
0.12 & \end{array}$ & $\begin{array}{ll}15.26 & \pm \\
6.58 & \end{array}$ & $\begin{array}{l}11.85 \pm \\
2.31\end{array}$ & $\begin{array}{l}1.06 \pm \\
0.06\end{array}$ \\
\hline P-value & 0.044 & 0.013 & 0.064 & 0.012 & 0.023 & 0.125 & 0.639 & 0.890 & 0.001 & 0.349 & 0.310 \\
\hline
\end{tabular}


Table 3: Incidence of Thromboembolic complication and infection in the study group revealed that only 5 children had simple infections in the form of 3 cases of gastroenteritis and 2 cases of bronchitis.

\begin{tabular}{|l|l|l|}
\hline \multirow{2}{*}{ COMPLICATIONS } & \multicolumn{2}{|c|}{ Control group } \\
\cline { 2 - 3 } & No. & $\%$ \\
\hline $\begin{array}{l}\text { Thromboembolic } \\
\text { complication }\end{array}$ & 0 & 0.00 \\
\hline Infection & 5 & 18.55 \\
\hline
\end{tabular}

Table 4: Relation among the study group between age and sex of patients with complication (thromboembolic complications and infections) or not which was statistically non-significant.

\begin{tabular}{|l|l|l|l|}
\hline & Non complicated & Complicated & P-value \\
\hline $\begin{array}{l}\text { Sex } \\
\text { Male } \\
\text { Female }\end{array}$ & $\begin{array}{l}\text { No. } 22 \\
10(44.5 \%)\end{array}$ & $\begin{array}{l}3(60.0 \%) \\
2(40.0 \%)\end{array}$ & 0.825 \\
\hline $\begin{array}{l}\text { Age } \\
\text { Mean } \pm \text { SD } \\
\text { Range }\end{array}$ & $\begin{array}{l}5.91 \pm 1.93 \\
3-10\end{array}$ & $\begin{array}{l}5.20 \pm 0.84 \\
4-6\end{array}$ & 0.433 \\
\hline
\end{tabular}




\section{Table 5:}

Relation between frequencies of relapse with presence of complication or not which was statistically insignificant.

\begin{tabular}{|c|c|c|c|}
\hline Frequency of relapse & $\begin{array}{l}\text { Non } \\
\text { complicated }\end{array}$ & Complicated & $\begin{array}{l}\text { P- } \\
\text { value }\end{array}$ \\
\hline No. = 22 & No. $=\mathbf{5}$ & \\
\hline $\begin{array}{c}\text { No. of relapse }<3 \\
\text { more relapse 3 or }\end{array}$ & $12(54.5 \%)$ & $3(60.0 \%)$ & 0.825 \\
\hline
\end{tabular}

Table 6: correlation between Antithrombin III levels in study group with other samples collected during relapse which was statistically significant regarding albumin, total protein levels and $\mathrm{A} / \mathrm{C}$ ratios.

\begin{tabular}{|l|c|c|}
\hline \multicolumn{1}{|c|}{ AT III (ng/ml) 1st Sample } & R & p-value \\
\hline Albumin (mg/dl) 1st Sample & $0.814^{* *}$ & 0.000 \\
\hline Total protein (g/dl) 1st Sample & $0.477^{*}$ & 0.012 \\
\hline Urea (mg/dl) 1st Sample & 0.063 & 0.757 \\
\hline Creatinine (mg/dl) 1st Sample & -0.064 & 0.750 \\
\hline Cholesterol (mg/dl) 1st Sample & -0.158 & 0.431 \\
\hline Triglycerides (mg/dl) 1st Sample & -0.155 & 0.439 \\
\hline Platelets (1000/mcl) 1st Sample & -0.301 & 0.127 \\
\hline PT (sec) 1st Sample & -0.029 & 0.886 \\
\hline INR 1st Sample & -0.124 & 0.537 \\
\hline A/C ration 1st Sample & $-0.483^{*}$ & 0.011 \\
\hline
\end{tabular}

Discussion

In the current study we found that during relapse mean serum antithrombin 
III level in the study group (81.74 \pm $20.1 \mathrm{ng} / \mathrm{ml}$ ) was statistically significantly decreased in relation with the control group $(170.77 \pm 11.03 \mathrm{ng} / \mathrm{ml})$ which was due to heavy proteinuria that occurs in nephrotic syndrome with subsequent decrease in total protein level, then 6 weeks after corticosteroid therapy serum antithrombin iii level was improved (mean $168.1 \pm 13.1 \mathrm{ng} / \mathrm{ml})$. This was concordant with $\mathrm{Lu} \mathrm{Z}$ et al. (2017) [9] study that was conducted on study group of 49 nephrotic children (30 boys and 19 girls) with a mean age of 6. 5+/-4.9 years (range 1-16 years) and a control group included 17 healthy children .The mean antithrombin III level of the study group was $68.2+/$ $23.4 \%$ at the onset of the disease, which was significantly lower than the level of the control group (84.0+/-7. 6\%). Plasma AT III levels increased to $74.4+/-15.3 \%$ after corticosteroid treatment. We also found that mean serum albumin level was statistically significantly decreased during relapse in the study group (1.87 \pm $0.48 \mathrm{mg} / \mathrm{dl}$ ) in relation to the control group $(4.08 \pm 0.45 \mathrm{mg} / \mathrm{dl})$ due to heavy proteinuria, then 6 weeks after steroid therapy albumin level was improved in the study group $(3.58 \pm 0.48 \mathrm{mg} / \mathrm{dl})$. Similarly, Özkayın et al., (2004)[10] in his study that was performed on 26 children with minimal change nephrotic syndrome and 30 healthy children found that during relapse mean serum albumin level of cases was $(2.29 \pm 0.54 \mathrm{mg} / \mathrm{dl})$. And after steroid therapy the mean serum albumin level was $(4.30 \pm 0.62 \mathrm{mg} / \mathrm{dl})$. There was statistically significantly increase in mean serum cholesterol level $(359.30 \pm 104.83) \mathrm{mg} / \mathrm{dl}$ in relation to that of the control group $(168.44 \pm 17.37 \mathrm{mg} / \mathrm{dl})$ during relapse, and 6 weeks after steroid therapy the mean serum cholesterol level $(207.44 \pm 24.00$ $\mathrm{mg} / \mathrm{dl}$ ) dropped but still slightly higher than that of the control group(168.44 \pm $17.37 \mathrm{mg} / \mathrm{dl}$ ), and mean serum triglycerides level during relapse $(295.89 \pm 66.25 \mathrm{mg} / \mathrm{dl})$ in the study group also was statistically significantly increased in relation with the control group $(140.63 \pm 18.29 \mathrm{mg} / \mathrm{dl})$, and its mean level $(167.78 \pm 20.91 \mathrm{mg} / \mathrm{dl})$ also dropped after 6 weeks of steroid therapy but still slightly higher than that of the control group $(140.63 \pm 18.29 \mathrm{mg} / \mathrm{dl})$ which was due to increased synthesis of lipoproteins that accompany increased hepatic albumin synthesis due to hypoalbuminemia. Similarly, Dnyanesh et al. (2014) [11] in his study that was conducted on 30 children with nephrotic syndrome, aged between 0-12 years and 10 
health children as a control group found that the mean serum cholesterol and tri glycerides levels in the study group was elevated in relation with the control group (mean serum cholesterol level (190.10 $\mathrm{mg} / \mathrm{dl}$ ), mean serum triglycerides level $(92.70 \mathrm{mg} / \mathrm{dl})$. But in contrast, he found that after 4 weeks of steroid therapy there was no significant change in the mean serum cholesterol or triglycerides levels.

As regarding platelet count in our study we found that during relapse mean platelet count $(489.33 \pm 65.90 / \mu \mathrm{L})$ was statisticaly higher than that of the control group $(268.78 \pm 83.32 / \mu \mathrm{L})$. This was concordant with Gulleroglu et al. (2014)[12] study that was conducted on Fifty-five children (30 girls, 25 boys) with nephrotic syndrome as a study group and 29 healthy children (18 girls, 11 boys) as a control group. He found that mean platelet count in the patient group $(403,112 \pm 185,605 / \mu \mathrm{L})$ was significantly higher than that of control group $(326,896$ $\pm 68,765 / \mu \mathrm{L})$. The pathogenesis of thrombocytosis seems to be multifactorial may be due to long use of steroid therapy or due to hypercholesterolemia but the exact cause is unknown.
In our study there was no statistical significance between the study and the control group as regarding the bleeding profile. Similarly, Mittal et al. (2013)[13] study that was conducted on twenty nine children with the steroid responsive nephrotic syndrome, found that there was no statistical significance as regarding prothrombin time as the mean prothrombin times before (PT1) and after the steroid therapy (PT2) were $15.17 \mathrm{~s}$ and $15.93 \mathrm{~s}$ respectively, which were within normal limits and the difference was not significant. In contrast the partial thromboplastin times were $36.21 \mathrm{~s}$ and 39.31s respectively before (PTT1) and after (PTT2) the steroid therapy. The difference was significant, with a $\mathrm{p}$ value of $<0.05$.

In our study as regarding infection there were no serious infections among the study group only 5 cases (18.5\%), 3 of them had gastroenteritis and the other 2 cases had bronchitis during relapse. In contrast to our results WEI et al. (2012) [14] study that was conducted over 176 children found that $19 \%$ of the study group was associated with major infections. Pneumonia was the most common infection (49\%), followed by 
urinary tract infection (UTI), bacteremia/sepsis, peritonitis and cellulitis. Pneumonia was the most common infection among children age younger than 10 years, whereas UTI was more common among children aged greater than 10 years.

In our study we found that during relapse there was positive correlation between antithrombin III level and albumin and subsequent total protein levels, and negative correlation between antithrombin III level and $\mathrm{A} / \mathrm{C}$ ratio due to increased renal loss to low molecular weight protein will lower their levels in blood and increase protein level in urine. Also we found that there was negative correlation between antithrombin III level and cholesterol level that may be due to hypoproteinemia that activates liver lipoproteins synthesis. Similarly Citak et al. (2000) [15] study that was conducted on 66 children divided into two groups, the first group consisted of 49 nephrotic children (30 boys and 19 girls) with a mean age of $6.5+/-4.9$ years (range 1-16 years). The control group included 17 healthy children ( 9 boys and 8 girls), during relapse he found also a positive correlation between serum antithrombin III level and the serum level of albumin and total proteins. Also he found negative correlation between serum antithrombin III and cholesterol levels.

\section{Conclusion:}

Nephrotic syndrome is one of the most common pediatric kidney diseases.it cause heavy proteinuria that lead to loss of many important proteins as antithrombin III. In our study we found that serum Antithrombin III level is significantly decreased in children with nephrotic syndrome and it correlated well serum albumin. Despite of the hypercoagulable state no thromboembolic complications can be detected in children with nephrotic syndrome.

\section{References:}

1- Eddy A and Symons J (2003). Nephrotic syndrome in childhood. The Lancet, 362.9384: 629-39.

\section{2- Kerlin B, Blatt N, Fuh B et al} (2009). Epidemiology and risk factors for thromboembolic complications of childhood nephrotic syndrome: a Midwest Pediatric Nephrology Consortium (MWPNC) study. The Journal of pediatrics, 155.1: 105-110. 
3- Haraldsson B, Nystrom J and Deen $W$ (2008). Properties of the glomerular barrier and mechanisms of proteinuria. Physiological reviews, 88(2), 451-487.

\section{4- McCampbell $\mathrm{K}$ and Wingert $\mathrm{R}$} (2012). Renal stem cells: fact or science fiction?. Biochemical Journal, 444(2), 153-168.

5- Caridi G, Trivelli A, SannaCherchi S et al (2010). Familial forms of nephrotic syndrome. Pediatr Nephrol; 25(2):241-52.

6- Mahmoodi B, Waanders F, Veeger $\mathbf{N}$ et al (2008). High absolute risks and predictors of venous and arterial thromboembolic events in patients with nephrotic syndrome: results from a large retrospective cohort study. Circulation, 117(2), 224-230.

7- Yamashiro K, Kiryu J, Tsujikawa A, et al. (2001). Inhibitory effects of antithrombin III against leukocyte rolling and infiltration during endotoxin-induced uveitis in rats. Invest Ophthalmol Vis Sci. 42(7):1553- 60.

8- Maclean $P$ and Tait $R$ (2007). Hereditary and acquired antithrombin deficiency: epidemiology, pathogenesis and treatment options. Drugs, 67(10):1429-40.

9- Lu Z, Wang $F$ and Liang $M$ (2017). Serpin C1/ Antithrombin III in kidney-related diseases. Clinical Science, 131.9: 823-831.

10- Özkayın N, Mir S, and Kavaklı K (2004). Hyper-coagulability risk factors in children with minimal change disease and the protective role of protein-C activity. International urology and nephrology, 36(4), 599-603.

\section{1- Dnyanesh D, Dnyanesh S and} Shenoy V (2014). A study of serum lipids in nephrotic syndrome in children. IOSRJDMS,13.3: 1-6.

\section{2- Gulleroglu K, Yazar B, Sakalli} $H$ et al (2014). Clinical importance of mean platelet volume in children with nephrotic syndrome. Renal failure, 36.5: 663-665.

\section{3- Mittal A, Aggarwal K, Saluja S} et al (2013) . Platelet functions and coagulation changes in Indian children with nephrotic syndrome. Journal of clinical and diagnostic research: JCDR, 7.8: 1647. 


\section{4- WEI C, YU I, LIN H et al}

(2012). Occurrence of infection among children with nephrotic syndrome during hospitalizations. Nephrology, 17.8: 681688.

15- Citak A, Emre S, Sairin A et al (2000). Hemostatic problems and thromboembolic complications in nephrotic children. Pediatr Nephrol,14.2: 138-142. 